\title{
Kandungan Logam Berat Timbal (Pb) Dan Kadmium (Cd) Pada Air, Sedimen Dan Organ Mangrove Di Perairan Tulehu
}

\author{
Nur Alim Natsir'1, Yusrianti Hanike², Muhammad Rijal, Suhaedir Bachtiar \\ ${ }^{1,3}$ Program Studi Pendidikan Biologi, Fakultas Ilmu Tarbiyah dan Keguruan \\ Institut Agama Islam Negeri Ambon \\ 2 Jurusan Manajemen Bisnis Syariah, Fakultas Syariah dan Ekonomi Islam \\ Institut Agama Islam Negeri Ambon \\ ${ }^{4}$ SMPN 2 Batang, Sulawesi Selatan \\ ${ }^{1}$ E-mail: nuralimnatsir@gmail.com \\ ${ }^{2}$ E-mail: yusriantihanike@iainambon.ac.id \\ ${ }^{3}$ E-mail: rijal_rijal82@yahoo.co.id \\ ${ }^{4}$ E-mail: subha.3g@gmail.com
}

\begin{abstract}
Abstrak: Perbedaan akumulasi logam berat timbal dan kadmium pada air, sedimen dan organ mangrove (akar, batang dan daun) ditemukan di perairan Tulehu Provinsi Maluku. Sampel diambil dari tiga stasion pengamatan yaitu pemberhentian kapal yang tidak beroperasi sekitar pelabuhan Tulehu (stasion 1), pelabuhan Tulehu (stasion 2) dan Muara Sungai Sepanjang Perairan Tulehu sebagai Kontrol (stasion 3). $\mathrm{Pb}$ dan $\mathrm{Cd}$ di analisis menggunakan Atomic Absorption Spectrophotometer. Kandungan $\mathrm{Pb}$ dan $\mathrm{Cd}$ di sedimen lebih tinggi daripada di air. Kandungan $\mathrm{Pb}$ dan $\mathrm{Cd}$ tertinggi ditemukan pada batang kemudian pada akar dan daun (batang > akar > daun). Mangrove merupakan salah satu organisme perairan yang mempunyai kemampuan untuk menyerap logam berat di lingkungan perairan.
\end{abstract}

\section{Kata Kunci: Mangrove; Pb; Cd; Logam Berat}

Abstract: Differences in the accumulation of heavy metals lead and cadmium in water, sediments and mangrove organs (roots, stems and leaves) found in the waters of Tulehu, Maluku Province. Samples were taken from three observation stations, namely stopping ships that are not operating (station 1), Tulehu harbor (station 2) and Control (station 3). $\mathrm{Pb}$ and $\mathrm{Cd}$ were analyzed using Atomic Absorption Spectrophotometer. $\mathrm{Pb}$ and $\mathrm{Cd}$ content in sediments is higher than in water. The highest $\mathrm{Pb}$ and $\mathrm{Cd}$ content is found in the stems then in the roots and leaves (stems> roots> leaves). Mangroves are one of the aquatic organisms that have the ability to absorb heavy metals in the aquatic environment.

Key words: Mangrove, Pb, Cd, Heavy Metal 
Perairan Negeri Tulehu merupakan wilayah pesisir yang memiliki sumberdaya hayati laut seperti mangrove, alga, mollusca dan lain-lain. Perairan. Pelabuhan Tulehu di Provinsi Maluku merupakan pelabuhan yang letaknya sangat strategis di Kecamatan Salahutu Kabupaten Maluku Tengah, dan berada di sepanjang perairan pesisir Tulehu. Pelabuhan ini merupakan jalur utama sistem transportasi laut masuk dan keluar ke Kota Ambon yang merupakan Ibukota Provinsi Maluku ke pulau-pulau di Kabupaten Maluku Tengah. Pelabuhan Tulehu merupakan jalur utama sistem transportasi laut sehingga perlu adanya pengembangan fasilitas-fasilitas yang ada di Pelabuhan Tulehu. Untuk mendukung kelancaran kegiatan bongkar muat barang dan naik turunnya penumpang di Pelabuhan Tulehu.

Aktivitas antropogenik oleh masyarakat di sekitar pelabuhan dan lalu lintas transportasi laut di pelabuhan Tulehu yang semakin berkembang diduga akan menghasilkan limbah domestik baik organik maupun anorganik yang berpotensi menjadi sumber masuknya logam berat ke dalam perairan Tulehu. Supriharyono (2007) menyatakan bahwa industri yang tidak dilengkapi oleh sistem pengelolaan limbah akan menghasilkan limbah yang mengandung air raksa $(\mathrm{Hg})$, besi $(\mathrm{Fe})$, mangan $(\mathrm{Mn})$, tembaga $(\mathrm{Cu})$, timbal $(\mathrm{Pb})$, seng $(\mathrm{Zn})$ kromium $(\mathrm{Cr})$, kadmium $(\mathrm{Cd})$ dan nikel (Ni). Pb dan $\mathrm{Cd}$ pada perairan ditemukan dalam bentuk terlarut dan tersuspensi. Keduanya dapat terikat pada partikel yang mengandung bahan organik dengan berbagai ukuran partikel. Logam-logam terikat masuk melalui proses agregasi dan akan mengendap di dasar perairan kemudian bersatu dengan sedimen (Harahap 2001). Menurut Sudarsono et al. (2005) partikel berukuran kecil umumnya memiliki kemampuan mengikat logam berat lebih tinggi. Indikator gangguan lingkungan di laut yang ditimbulkan dapat berupa kandungan logam berat dalam perairan Tulehu yang berasal dari kegiatan industri maupun alam. Kandungan logam berat yang menumpuk pada air laut dan sedimen akan masuk kedalam sistem rantai makanan dan berpengaruh pada kehidupan organisme perairan (Arsad dkk, 2012). Salah satu jenis logam berat yang memasuki perairan dan bersifat toksik adalah Kadmium (Cd) dan Timbal $(\mathrm{Pb})$. Kadmium $(\mathrm{Cd})$ dan Timbal $(\mathrm{Pb})$ merupakan logam berat yang sangat berbahaya karena tidak dapat dihancurkan (non degradable) oleh organisme hidup dan dapat terakumulasi ke lingkungan, terutama mengendap di dasar perairan membentuk senyawa kompleks bersama bahan organik dan anorganik. Organisme perairan yang dapat menerima dampak langsung pencemaran logam berat adalah diantaranya tanaman mangrove.

Area hutan mangrove akan menjadi daerah penumpukkan limbah, terutama jika polutan yang masuk ke dalam lingkungan estuari melampaui kemampuan pemurnian alami oleh air (Collen et al., 2011; Mulyadi et al., 2009). Mangrove yang tumbuh di ujung sungai besar berperan sebagai penampung terakhir bagi limbah dari industri di perkotaan dan permukiman bagian hulu yang terbawa aliran sungai. Limbah padat dan cair yang terlarut dalam air sungai terbawa arus menuju muara sungai dan laut lepas. Kumar et al., (2011) menggunakan bagian tanaman mangrove (akar, batang, daun) dan sedimen yang 
dianalisis untuk menemukan adanya akumulasi logam. Dari analisis logam berat dalam Avicennia marina menunjukkan hasil bahwa akumulasi dari semua logam berat (kecuali Cd) dalam jaringan akar lebih tinggi dibandingkan dengan batang, daun dan sedimen sekitarnya.

Penelitian tentang status pencemaran logam berat di wilayah perairan Tulehu masih terus dilakukan baik pada air, sedimen maupun organ mangrove. Penelitian bertujuan untuk menganalisis kandungan logam berat $\mathrm{Pb}$ dan $\mathrm{Cd}$ di air, sedimen dan organ mangrove (akar, batang dan daun).

\section{METODE PENELITIAN}

Penelitian ini dilakukan pada tanggal 13 Mei 2019 - 31 Juli 2019 di Perairan Tulehu Kabupaten Maluku Tengah Provinsi Maluku dan di Laboratorium Universitas Muhammadiyah Malang. Metode yang digunakan adalah survei di tiga stasiun yang terletak di sekitar Pelabuhan Tulehu berdasarkan kondisi perairan dan distribusi aktivitas antropogenik yaitu Stasion 1 di Pelabuhan Tulehu 1 (Sandar Kapal yang tidak beroperasi dan antropogenik), Stasion 2 Pelabuhan Tulehu 2 (pelabuhan penyeberangan) dan Stasion 3 di Muara Sungai sepanjang perairan Tulehu mewakili daerah yang jauh dari sumber pencemar (kontrol), kemudian dilakukan pengambilan air, sedimen dan organ mangrove serta pengukuran parameter kualitas air pada masing-masing stasiun. Sampel air diambil pada setiap lokasi penelitian dengan tiga kali ulangan masing-masing sebanyak $500 \mathrm{ml}$ pada kedalaman $\pm 30 \mathrm{~cm}$ dari permukaan air. Sampel sedimen diambil menggunakan Ekman dredge Sampel sedimen diambil pada tiap stasiun penelitian dengan tiga kali pengulangan masing-masing sebanyak $1 \mathrm{~kg}$, kemudian sampel dimasukkan ke dalam plastik sampel dan diberi label. Pengambilan sampel mangrove dilakukan berdasarkan Ulqodry (2001),yaitu mangrove yang diambil untuk sampel adalah pohon. Jaringan mangrove yang digunakan adalah akar, daun, batang yang terkena pasang surut air laut $( \pm 1,3 \mathrm{~cm})$, dari jalur transek tersebut diambil 3 titik pengambilan sampel pada setiap lokasi dengan jarak antar titik pengambilan sampel 50 meter.

\section{Analisis Kandungan Logam Berat $\mathrm{Pb}$ dan $\mathrm{Cd}$ pada Air}

Alat yang digunakan untuk analisis logam berat dalam air ialah Atomic Absorption Spectrometry $(A A S)$ yang memiliki deteksi limit $0.001 \mathrm{ppm}$. Contoh air sebanyak $100 \mathrm{ml}$ disaring menggunakan kertas saring $0,45 \mu \mathrm{m}$ dan dimasukan pada corong pemisah. Selanjutnya ditambahkan 2 tetes asam nitrat $\left(\mathrm{HNO}_{3}\right)$ dan dihomogenkan. Larutan $\mathrm{HNO}_{3}$ berfungsi untuk menurunkan $\mathrm{pH}$. Tahap berikutnya contoh air ditambahkan $1 \mathrm{ml}$ Amonium Pirolidin Ditiokarbonat (APDC), kemudian dihomogenkan. Pereaksi APDC berfungsi untuk membentuk senyawa organik komplek yang tidak larut pada fase air. Selanjutnya ditambahkan $10 \mathrm{ml}$ Metil Iso Butil Keton (MIBK), dihomogenkan selama 30 detik dan disimpan hingga terbentuk dua lapisan. Fase organik ditampung untuk dianalisis menggunakan AAS (APHA 2012). 


\section{Analisis Logam Berat pada Sedimen dan Mangrove}

Alat yang digunakan untuk analisis logam berat dalam sedimen dan mangrove ialah Atomic Absorption Spectrometry (AAS) yang memiliki deteksi limit $0.001 \mathrm{ppm}$. Contoh sedimen dan mangrove dikeringkan menggunakan oven. Selanjutnya contoh dihaluskan menggunakan cawan porselin, ditimbang sebanyak 2 gram dan dimasukkan ke dalam gelas beker $100 \mathrm{ml}$. Contoh ditambah $10 \mathrm{ml} \mathrm{HNO}_{3}$ dan dipanaskan menggunakan hotplat pada suhu $85^{\circ} \mathrm{C}$. Ketika volume larutan tersisa 1-2 ml, larutan

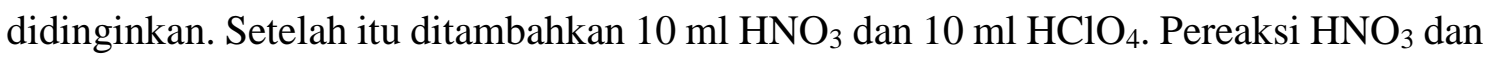
$\mathrm{HClO}_{4}$ berfungsi untuk memutus ikatan logam berat dengan bahan organik pada contoh. Selanjutnya contoh dihomogenkan dan dipanaskan kembali pada hotplate sampai uap $\mathrm{HClO}_{4}$ hilang. Jika larutan sudah jernih, ditambahkan $100 \mathrm{ml}$ akuades untuk pengenceran, kemudian disaring menggunakan kertas saring 0,45 $\mu \mathrm{m}$. Hasil saringan selanjutnya dianalisis menggunakan AAS (APHA 2012).

Data kandungan logam berat $\mathrm{Pb}$ dan $\mathrm{Cd}$ yang diperoleh ditampilkan dalam bentuk tabel, grafik dan histogram kemudian dibahas secara deskriptif. Hasil analisis logam berat $\mathrm{Pb}$ dan $\mathrm{Cd}$ dalam air dibandingkan dengan nilai standar Baku Mutu Air Laut untuk Biota laut (Kepmen LH No. 51 Tahun 2004). Kandungan logam berat $\mathrm{Pb}$ dan $\mathrm{Cd}$ dalam sedimen dibandingkan dengan standar baku mutu CCME,ANZECC 2002 dan NOAA 1999. Kandungan logam berat $\mathrm{Pb}$ dan $\mathrm{Cd}$ dalam organ mangrove dibandingkan dengan baku mutu SNI 7387:2009 tentang Batas Maksimum Cemaran Logam dalam Bahan Pangan. Analisis ANOVA (One-Way ANOVA $\mathrm{p}<0,05$ ) juga digunakan untuk mengetahui: perbedaan akumulasi logam berat $\mathrm{Pb}$ dan $\mathrm{Cd}$ pada masing-masing Stasion pengambilan sampel. Selain itu One-Way ANOVA $p<0,05$ digunakan untuk mengetahui perbedaan akumulasi logam $\mathrm{Pb}$ dan $\mathrm{Cd}$ pada akar, batang dan daun.

\section{HASIL DAN PEMBAHASAN}

\section{Deskripsi Lokasi}

Perairan Negeri Tulehu merupakan wilayah pesisir yang memiliki sumberdaya hayati laut seperti mangrove, alga, mollusca dan lain-lain. Perairan Tulehu memiliki pelabuhan penyeberangan yang letaknya sangat strategis di Kecamatan Salahutu Kabupaten Maluku Tengah, dan berada di sepanjang perairan pesisir Tulehu. Pelabuhan ini merupakan jalur utama sistem transportasi laut masuk dan keluar ke Kota Ambon yang merupakan Ibukota Provinsi Maluku ke pulau-pulau di Kabupaten Maluku Tengah. Penurunan kualitas air baik secara langsung maupun tidak langsung diduga akan mempengaruhi biota perairan termasuk mangrove. Perairan sekitar pelabuhan Tulehu sangat rawan terhadap pencemaran logam berat yang disebabkan oleh buangan limbah dari masyarakat maupun dari transportasi laut. Kapal yang melewati perairan tersebut sangat berpotensi untuk mengeluarkan buangan-buangan yang mengandung logam berat sehingga terjadi pencemaran laut. 


\section{Kandungan Logam Berat $\mathrm{Pb}$ dan $\mathrm{Cd}$ pada Air}

Hasil analisis One-way ANOVA menunjukkan bahwa logam berat $\mathrm{Pb}$ dan $\mathrm{Cd}$ di perairan Tulehu menunjukkan ada satu perlakuan yang berbeda di setiap titik sampling $(\mathrm{P}=0,000)$. Hasil pengukuran konsentrasi timbal dalam air laut pada 3 titik sampling berkisar antara $0,001942 \mathrm{mg} / \mathrm{L}-0,08918 \mathrm{mg} / \mathrm{L}$ dengan rata-rata $0,05314 \mathrm{mg} / \mathrm{L}$ (Gambar 1). Konsentrasi tertinggi sebesar $0,08918 \mathrm{mg} / \mathrm{L}$ terdeteksi pada sampel di titik sampling 1. Sedangkan kandungan $\mathrm{Cd}$ dalam air laut pada 3 titik sampling berkisar antara 0,000656 $\mathrm{mg} / \mathrm{L}$ - 0,002894 mg/L dengan rata-rata 0,001725 mg/L (Gambar 2). Konsentrasi tertinggi sebesar $0,002894 \mathrm{mg} / \mathrm{L}$ terdeteksi pada sampel di titik sampling 1 . Rata-rata kandungan timbal $(\mathrm{Pb})$ dan kadmium $(\mathrm{Cd})$ yang didapatkan telah melebihi batas toleransi yang dianjurkan, sehingga tingginya kandungan timbal dalam air laut di perairan Tulehu akan mengendap dan terakumulasi ke dalam sedimen.

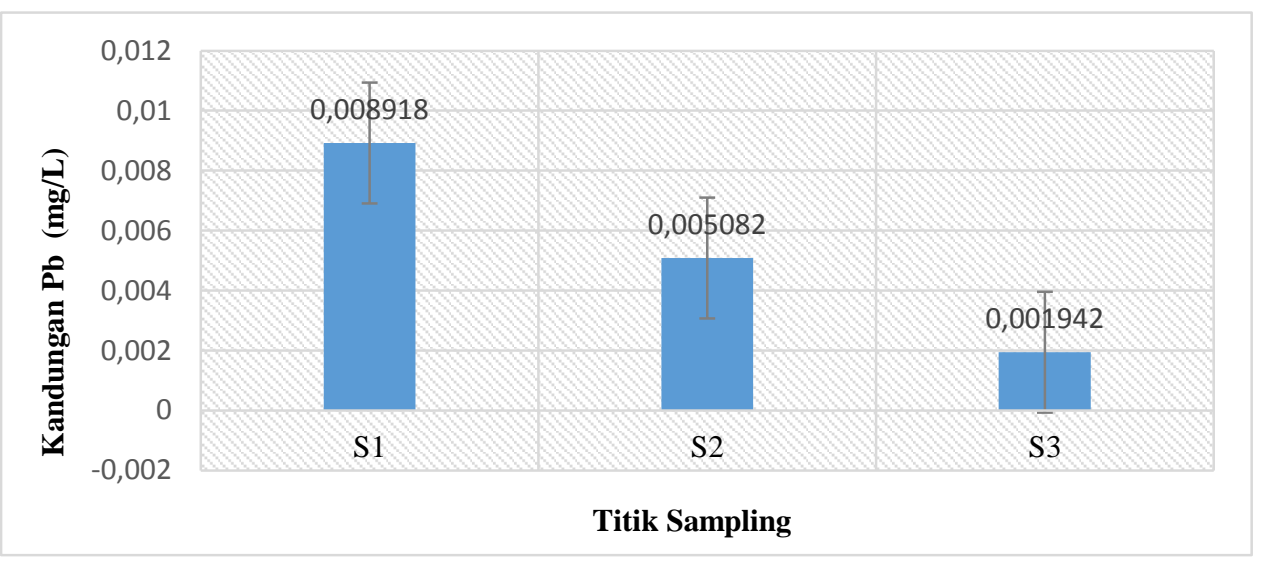

Gambar 1. Kandungan timbal (Pb) pada air

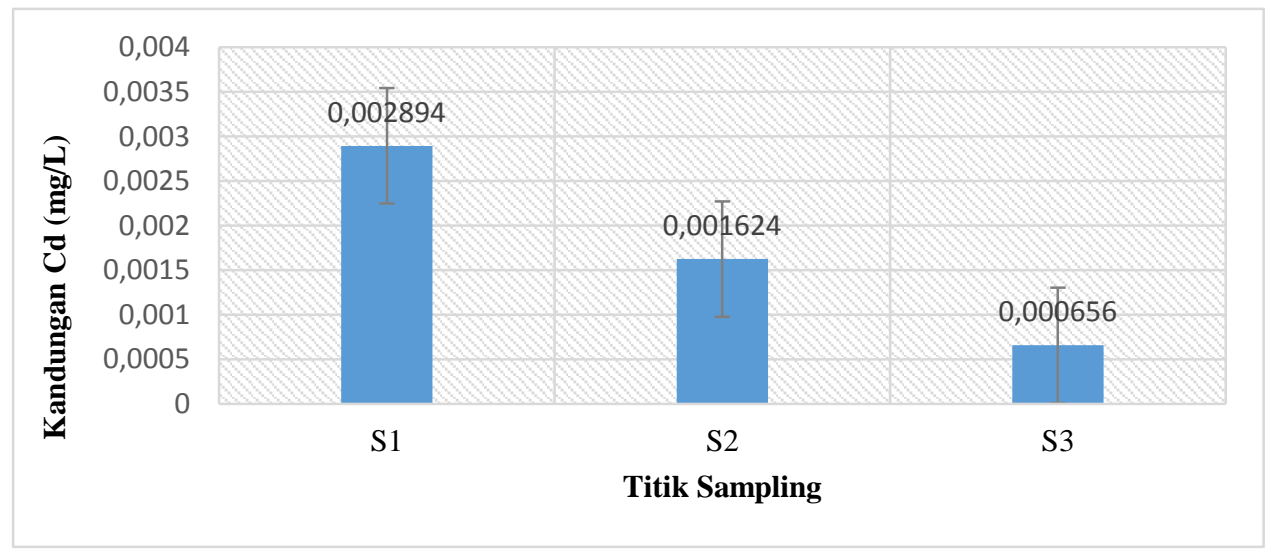

Gambar 2. Kandungan Logam Berat $\mathrm{Pb}$ dan Cd pada Sedimen

Berdasarkan uji ANOVA kandungan $\mathrm{Pb}$ dan $\mathrm{Cd}$ menunjukkan ada satu perlakuan yang berbeda di setiap titik sampling $(\mathrm{P}=0,000)$. Hasil pengukuran konsentrasi $\mathrm{Pb}$ pada sedimen di perairan Tulehu menunjukkan kisaran rata-rata antara 3,6479-7,6955 mg/Kg. 
Rata-rata konsentrasi timbal di perairan Tulehu adalah 5,4104 mg/Kg. Konsentrasi tertinggi berada pada titik sampling 1 (Pelabuhan Tulehu) dengan 7,6955 mg/Kg dan terendah pada titik sampling 3 sebesar 3,6479 mg/Kg. Sedangkan Cd pada sedimen di perairan Tulehu menunjukkan kisaran rata-rata antara $0,6011-1,2520 \mathrm{mg} / \mathrm{Kg}$. Rata-rata konsentrasi timbal di perairan Tulehu adalah $0,8917 \mathrm{mg} / \mathrm{Kg}$. Konsentrasi tertinggi berada pada titik sampling 1 (Pelabuhan Tulehu) dengan $1,2520 \mathrm{mg} / \mathrm{Kg}$ dan terendah pada titik sampling 3 sebesar $0,6011 \mathrm{mg} / \mathrm{Kg}$. Konsentrasi timbal dan kadmium dalam sedimen yang diperoleh masih di bawah batas aman toleransi apabila dibandingkan dengan baku mutu $($ CCME $2002=30,2 \mathrm{mg} / \mathrm{kg})$.

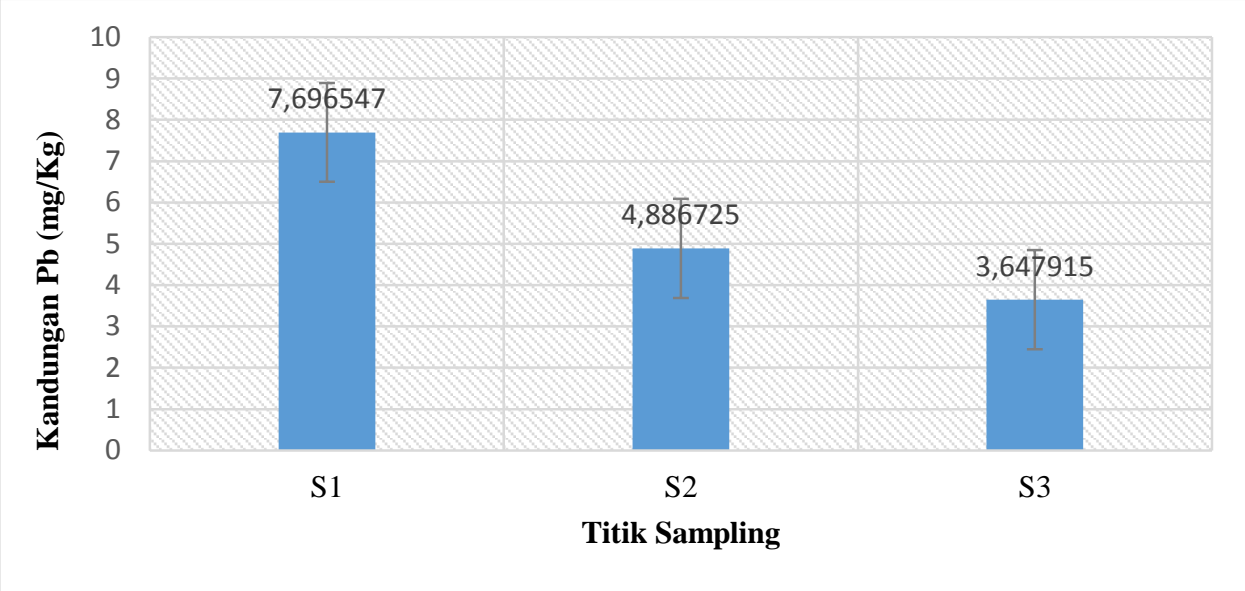

Gambar 3. Kandungan Timbal (Pb) pada Sedimen

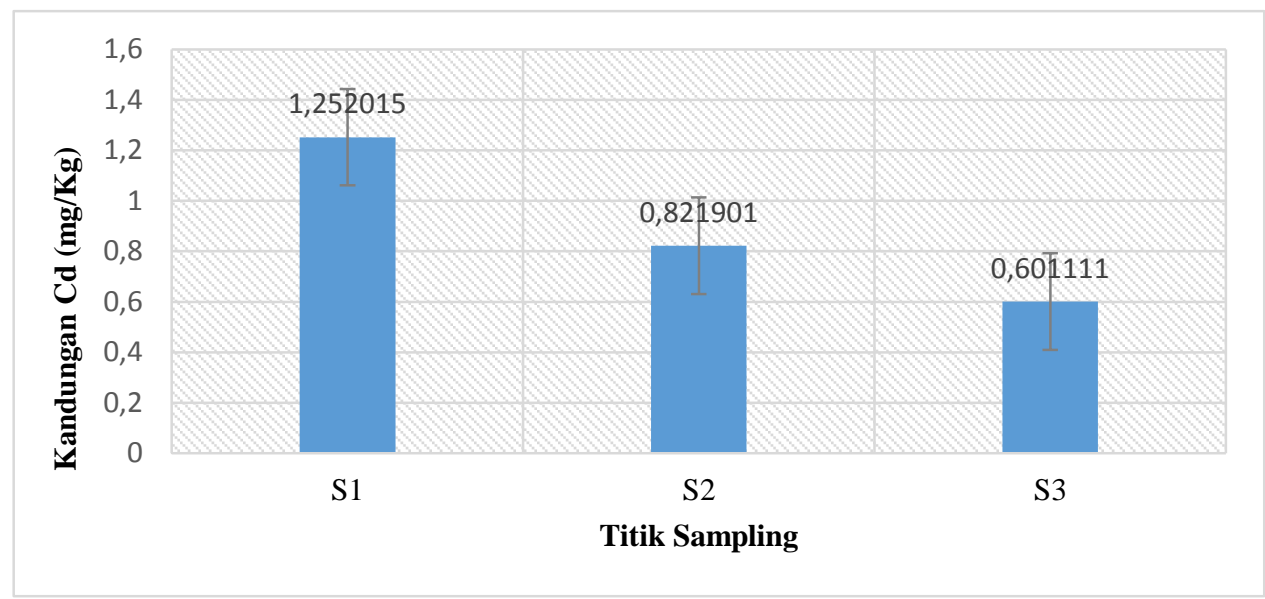

Gambar 4. Kandungan Logam Berat pada Akar, Batang dan Daun Mangrove

Hasil penelitian di perairan Tulehu menunjukkan bahwa kandungan logam berat pada batang lebih tinggi dibandingkan pada akar dan daun. Tabel 1 menunjukkan terdapat perbedaan kandungan logam berat baik $\mathrm{Pb}$ dan $\mathrm{Cd}$ pada akar, batang dan daun mangrove pada tiga stasion pengamatan. 
Tabel 1. Kandungan logam berat $\mathrm{Pb}$ dan $\mathrm{Cd}$ pada akar, batang dan daun mangrove di perairan Tulehu

\begin{tabular}{|c|c|c|c|c|c|c|c|}
\hline \multirow{2}{*}{$\begin{array}{c}\text { Titik } \\
\text { Sampling }\end{array}$} & \multirow[t]{2}{*}{ Lokasi } & \multicolumn{2}{|c|}{ Akar } & \multicolumn{2}{|c|}{ Batang } & \multicolumn{2}{|c|}{ Daun } \\
\hline & & $\begin{array}{c}\mathrm{Pb} \\
(\mathrm{mg} / \mathrm{Kg})\end{array}$ & $\begin{array}{c}\text { Cd } \\
(\mathrm{mg} / \mathrm{Kg})\end{array}$ & $\begin{array}{c}\text { Pb } \\
(\mathrm{mg} / \mathrm{Kg})\end{array}$ & $\begin{array}{c}\text { Cd } \\
(\mathrm{mg} / \mathrm{Kg})\end{array}$ & $\begin{array}{c}\text { Pb } \\
(\mathrm{mg} / \mathrm{Kg})\end{array}$ & $\begin{array}{c}\text { Cd } \\
(\mathrm{mg} / \mathrm{Kg})\end{array}$ \\
\hline 1 & $\begin{array}{c}\text { Sandar } \\
\text { Kapal } \\
\text { (doc) }\end{array}$ & 2,509627 & 0,313193 & 4,290346 & 0,59704 & 1,008679 & 0,192611 \\
\hline 2 & $\begin{array}{c}\text { Pelabuhan } \\
\text { Tulehu }\end{array}$ & 1,568149 & 0,198181 & 2,688421 & 0,386274 & 0,956192 & 0,120596 \\
\hline 3 & $\begin{array}{c}\text { Kontrol } \\
\text { (Muara } \\
\text { Sungai } \\
\text { Sepanjang } \\
\text { Perairan } \\
\text { Tulehu) }\end{array}$ & 1,168957 & 0,147234 & 2,00927 & 0,285158 & 0,473816 & 0,090922 \\
\hline \multicolumn{2}{|c|}{ Rata-rata } & $1,748911^{b}$ & 0,219536 & $2,99601^{b}$ & 0,422824 & $0,812896^{b}$ & 0,13471 \\
\hline \multicolumn{2}{|c|}{${ }^{\text {a} B a k u ~ m u t u ~}$} & $0,3^{a}$ & $0,5^{a}$ & $0,3^{\mathbf{a}}$ & $0,5^{a}$ & $0,3^{\mathbf{a}}$ & $0,5^{a}$ \\
\hline
\end{tabular}

SNI 7387:2009 ${ }^{\text {a }}$ Melebihi baku mutu ${ }^{\mathrm{b}}$

\section{Kandungan Logam Berat $\mathrm{Pb}$ dan $\mathrm{Cd}$ pada Air dan Sedimen}

Kandungan logam berat $\mathrm{Pb}$ dan $\mathrm{Cd}$ di perairan Tulehu menunjukkan telah melebihi baku mutu air laut untuk biota laut yaitu sebesar 0,008 mg/l (KepMen LH No. 51 Tahun 2004). Tingginya konsentrasi kandunga $\mathrm{Pb}$ dan $\mathrm{Cd}$ pada titik sampling 1 dibandingkan titik sampling yang lain diduga berasal dari limbah buangan kapal di lokasi pemberhentian kapal sementara oleh nelayan, mengganti bahan bakar, dan sedimentasi lumpur akibat pembuangan limbah cair dari aktivitas pelayaran, antropogenik dan limbah rumah tangga di sekitar perairan yang dibuang ke laut. Pada umumnya wilayah pesisir merupakan daerah yang rentan terhadap pencemaran akibat kesalahan dalam pengelolaannya karena menjadikan kawasan ini sebagai tempat pembuangan segala macam limbah yang berasal dari daratan oleh aktivitas manusia ke perairan laut.

Kandungan timbal dan kadmium dalam sedimen yang diperoleh masih di bawah batas aman toleransi apabila dibandingkan dengan baku mutu (IADC/CEDA (1997) = $30,2 \mathrm{mg} / \mathrm{kg}$ ). Oleh karena itu kandungan logam berat dalam sedimen di perairan Tulehu masih dalam batas toleransi bagi biota laut. Namun demikian berdasarkan IADC/CEDA (1997) kandungan Cd pada sedimen di perairan Tulehu menunjukkan pada level target dimana konsentrasi kontaminan yang ada pada sedimen memiliki nilai yang lebih kecil dari nilai level target, maka substansi yang ada pada sedimen tidak terlalu berbahaya bagi lingkungan namun jika dibiarkan sedimentasi komposisi logam berat akan mengalami peninngkatan.

\section{Kandungan Logam Berat pada Akar, Batang dan Daun Mangrove}

Hasil penelitian terhadap kandungan logam berat $\mathrm{Pb}$ pada akar mangrove menunjukkan kisaran antara $1,1689 \mathrm{mg} / \mathrm{Kg}-2,5096 \mathrm{mg} / \mathrm{Kg}$. Kandungan $\mathrm{Pb}$ pada titik 
sampling 1 lebih tinggi $(2,5096 \mathrm{mg} / \mathrm{Kg})$ dibandingkan dengan titik $2(1,5681 \mathrm{mg} / \mathrm{Kg})$ dan titik $3(1,16895 \mathrm{mg} / \mathrm{Kg})$. Nilai baku mutu logam berat timbal yaitu $0,3 \mathrm{mg} / \mathrm{kg}$ (SNI 7387:2009) dan 0,4 mg/kg (BPOM). Sedangkan kandungan Cd pada titik sampling 1 lebih tinggi $(0,3131 \mathrm{mg} / \mathrm{Kg})$ dibandingkan dengan titik $2(0,1981 \mathrm{mg} / \mathrm{Kg})$ dan titik 3 $(0,1472 \mathrm{mg} / \mathrm{Kg})$. Berdasarkan pedoman baku mutu lingkungan menurut Surat Keputusan Menteri Lingkungan Hidup Nomor: KEP-MEN LH No.51/MenKLH/2004, ambang batas $\mathrm{Cd}$ untuk wisata bahari adalah 0,002 ppm dan untuk biota adalah 0,001 ppm. Berdasarkan hasil kandungan logam berat Timbal dan Kadmium pada akar di perairan Tulehu menyatakan bahwa hasil telah melewati baku mutu yang ditetapkan pemerintah.

Tingginya kandungan logam berat $\mathrm{Pb}$ di akar diduga logam yang larut bersama limbah pelayaran, tumpahan minyak saat pengisian bahan bakar dan antropogenik di sekitar perairan Tulehu akan terserap dalam bentuk larutan disekitar akar (rizosfer) mangrove dengan cara translokasi di dalam tubuh tumbuhan. Setelah logam dibawa masuk ke sel akar menurut Zhu et al (1999) dalam Katipana (2015) menyatakan bahwa logam akan diangkut melalui jaringan pengangkut, yaitu xilem dan floem ke bagian tumbuhan lain. Untuk meningkatkan efisiensi pengangkutan, logam diikat oleh molekul khelat yang berfungsi mengikat logam dan dihasilkan oleh tumbuhan, misalnya fitokhelatin-glutation yang terikat pada Cd (Rijal. M, Rosmawati., Nur Alim., 2014).

Hasil penelitian menunjukkan bahwa kandungan $\mathrm{Pb}$ pada batang menunjukkan di titik sampling 1 lebih tinggi (4,2903 mg/Kg) dibandingkan dengan titik 2 (2,6884 mg/Kg) dan titik 3 (2,0092 mg/Kg). Berdasarkan pedoman baku mutu lingkungan menurut Surat Keputusan Menteri Lingkungan Hidup Nomor: KEP-MEN LH No.51/MenKLH/2004, ambang batas $\mathrm{Pb}$ untuk untuk biota adalah 0,008 ppm. Sedangkan kandungan $\mathrm{Cd}$ menunjukkan pada titik sampling 1 lebih tinggi $(0,5970 \mathrm{mg} / \mathrm{Kg})$ dibandingkan dengan titik $2(0,3862 \mathrm{mg} / \mathrm{Kg})$ dan titik $3(0,2851 \mathrm{mg} / \mathrm{Kg})$. Berdasarkan pedoman baku mutu lingkungan menurut Surat Keputusan Menteri Lingkungan Hidup Nomor: KEP-MEN LH No.51/MenKLH/2004, ambang batas Cd untuk untuk biota adalah 0,001 ppm. Akumulasi logam berat $\mathrm{Pb}$ pada tumbuhan mangrove yang tinggi maka kondisi lingkungan perairan di lokasi penelitian menunjukkan lebih tinggi dari ambang batas. Sampel batang tumbuhan mangrove yang diambil pada stasiun 1 menunjukkan tertinggi. Beberapa kemungkinan penyebab tingginya kadar $\mathrm{Pb}$ di stasiun 1 adalah pembuangan limbah ikan dari pedagang ikan sekitar perairan, limbah kapal dari pelabuhan Tulehu, dan antropogenik dari pemukiman warga sekitar perairan. Akumulasi logam berat $\mathrm{Cd}$ di semua titik lokasi penelitian menunjukkan telah melebihi ambang batas. Sifat kadmium yang mudah bereaksi akan membentuk kompleks dengan senyawa organik dan anorganik menyebabkan pencemaran terutama biota air seperti mangrove.

Hasil penelitian menunjukkan kandungan $\mathrm{Pb}$ pada daun mangrove di titik sampling 1 lebih tinggi $(1,0086 \mathrm{mg} / \mathrm{Kg})$ dibandingkan dengan titik $2(0,9561 \mathrm{mg} / \mathrm{Kg})$ dan titik $3(0,4738 \mathrm{mg} / \mathrm{Kg})$. Berdasarkan pedoman baku mutu lingkungan menurut Surat Keputusan Menteri Lingkungan Hidup Nomor: KEP-MEN LH No.51/MenKLH/2004, 
ambang batas $\mathrm{Pb}$ untuk untuk biota adalah $0,3 \mathrm{mg} / \mathrm{Kg}$. Sedangkan kandungan $\mathrm{Cd}$ pada daun di titik sampling 1 menunjukkan lebih tinggi $(0,1926 \mathrm{mg} / \mathrm{Kg})$ dibandingkan dengan titik $2(0,1205 \mathrm{mg} / \mathrm{Kg})$ dan titik $3(0,0909 \mathrm{mg} / \mathrm{Kg})$. Berdasarkan pedoman baku mutu lingkungan menurut Surat Keputusan Menteri Lingkungan Hidup Nomor: KEP-MEN LH No.51/MenKLH/2004, ambang batas Cd untuk untuk biota adalah 0,001 mg/Kg.

Kandungan logam berat timbal pada daun yang diperoleh dari lokasi penelitian telah melewati batas baku mutu yang ditetapkan oleh pemerintah. Daun adalah bagian dari tumbuhan mangrove dimana merupakan jaringan dengan tingkat akumulasi logam berat yang lebih tinggi jika dibandingkan dengan ranting. Kemungkinan hal ini disebabkan karena tingkat mobilitasi logam berat yang tinggi dan jaringan daun sebagai tempat penimbunan logam berat sebelum dilepas ke lingkungan (Rijal. M, 2010). Hal ini sesuai dengan pernyataan Chaney et al (1998) dalam Setiawan (2013) bahwa logam berat akan terdistribusi ke seluruh jaringan tanaman sampai daun, melalui proses uptake pada akar, ditahan pada jaringan, dan dilepas ke lingkungan melalui pelepasan daun. Pada stasiun 1 menunjukkan kandungan logam $\mathrm{Pb}$ pada daun yang tertinggi. Daun mangrove di stasiun ini dimungkinkan menyimpan translokasi penyerapan kontaminan seperti logam berat $\mathrm{Pb}$ yang telah terserap oleh akar. Penyerapan dan akumulai logam berat oleh tumbuhan dapat dibagi menjadi tiga proses, yaitu penyerapan logam oleh akar, translokasi logam dari akar ke bagian tumbuhan lain, dan lokalisasi logam pada bagian sel tertentu untuk menjaga agar tidak menghambat metabolisme tumbuhan tersebut. Dalam penelitian Sunarya, dkk (1991) menunjukkan bahwa tumbuhan dapat mengakumulasi $\mathrm{Pb}$ pada daun dan kulit batangnya.

Sedangkan kandungan logam berat kadmium $(\mathrm{Cd})$ yang ada di semua lokasi penelitian telah melebihi ambang batas yang ditetapkan. Dalam tubuh biota perairan jumlah logam yang terakumulasi akan terus mengalami peningkatan. Di samping itu, tingkatan biota dalam sistem rantai makanan turut menentukan jumlah $\mathrm{Cd}$ yang terakumulasi. Di mana pada biota yang lebih tinggi stratanya akan ditemukan akumulasi Cd yang lebih banyak,sedangkan pada biota top level merupakan tempat akumulasi paling besar. Bila jumlah Cd yang masuk tersebut melebihi ambang maka biota dari suatu level atau strata tersebut akan mengalami kematian dan bahkan kemusnahan (Nowrouzi, et. al., 2012).

\section{KESIMPULAN}

Kandungan logam berat $\mathrm{Pb}$ dan $\mathrm{Cd}$ pada air, sedimen dan organ (akar, batang dan daun) mangrove di perairan Tulehu menunjukkan bahwa akumulasi $\mathrm{Pb}$ dan $\mathrm{Cd}$ lebih banyak terdapat pada sedimen dan akar mangrove. Tumbuhan mangrove dapat dijadikan bioindikator tingkat pencemaran logam di lingkungan akuatik. 


\section{DAFTAR PUSTAKA}

APHA. (2012). Standart Method for The Examination of Water and Wastewater.22th edition. Washington, $3111 \mathrm{~b}$.

Arsad, M, Said,I, Suherman. (2012). Akumulasi Logam Timbal (Pb) dalam Ikan Belanak (Liza melinoptera) yang Hidup di Muara Poboya. Jurnal Akademika Kimia Volume 1, No. 4, 2012: 187-192 November 2012 ISSN 2302-6030. Pendidikan Kimia/FKIP - University of Tadulako, Palu - Indonesia 94118

Collen, John D., Jane E. Atkinson, and John E. Patterson. (2011). Trace Metal Partitioning in a Nearshore Tropical Environment: Geochemistry of Carbonate Reef Flats Adjacent to Suva Harbor, Fiji Islands. Pacific Science 65 (1) :95-107

Chaney RL., Bromilow, RH., Evans, A.A, (1982). Soil-Root Interface:Food Chain Contamination and Ecosystem Health. Madison WI: Soil Sci Soc Am 3:9-11

Harahap S. 2001. Tingkat pencemaran air kali cakung ditinjau dari sifat fisikakimia khususnya logam berat dan keanekaragaman jenis hewan benthos makro [tesis]. Bogor (ID): Bidang Studi Ilmu Pengelolaan Sumberdaya

IADC/CEDA Staff. (1997). Environmental Aspects of Dredging: 2a. Convention, Codes, and Conditions: Marine Disposal. Netherlands: International Association of Dredging Companies.

Katipana, D. (2015). Uji Kandungan Logam Berat Timbal (Pb) pada Kangkung Air (Ipomea aquticaf) di Kampus Unpatti Poka. Biopendix, Volume 1, Nomor 2, Maret 2015, hlm. 143-149

Keputusan Menteri Lingkungan Hidup No.51/Men KLH/I/2004 Tentang Baku Mutu Air Laut.

Kumar N.J.I; P.R. Sajish; Rita N Kumar; Basil George and Shailendra Viyol. (2011). Bioaccumulation of Lead, Zinc and Cadmium in Avicennia marina Mangrove Ecosystem near Narmada Estuary in Vamleshwar, West Coast of Gujarat, India. J. Int. Environmental Application \& Science, 6 (1): 008-013

Mulyadi, Edi., R. Laksmono., and D. Aprianti. (2009). Fungsi Mangrove Sebagai Pengendali Pencemar Logam Berat. Jurnal Ilmiah Teknik Lingkungan; 1 (Edisi Khusus) 33-39.

Nowrouzi M, Pourkhabbaz A, and Rezaei M. (2012). Bioaccumulation and Distributionof Metals in Sediments and AvicennaMarina Tissues in The Hara Biosphere Reserve, Iran. Bull Environ ContamToxicol.vol 89(4):799-804

Rijal, M., Rosmawati, T., Alim, N., \& Amin, M. (2014). Bioakumulation heavy metals lead $(\mathrm{Pb})$ and cadmium $(\mathrm{Cd})$ seagrass (Enhalus acroides) in Waai and Galala Island Ambon. IJSBAR, 16(2), 349-356.

Rijal, M. (2010). Bioakumulasi Logam Berat Timbal (Pb) dan Cadmium (Cd) pada Lamun (Enhalus Acroides) Di Perairan Waai dan Galala Ambon Sebagai Sumber Belajar Ekologi Pencemaran.(Tesis). DISERTASI dan TESIS Program Pascasarjana UM.

BIOLOGI SEL (VOL 8 NO 2 EDISI JUL-DES 2019 ISSN 2252-858X/E-ISSN 2541-1225) PAGE 158 
Rijal, M., Amin, M., Rohman, F., Suarsini, E., \& Natsir, N. A. Pistia stratiotes and Limnocharis Flava as Phytoremediation Heavy Metals Lead and Cadmium in the Arbes Ambon.

Rijal, M., Amin, M., Rochman, F., \& Suarsini, E. Response Growth and the Effectiveness of the Absorption of Heavy Metal B-Iii by Limnochris Flava on a Scale Laboratory.

Setiawan, H. (2013). Akumulasi dan Distribusi Logam Berat pada Vegetasi Mangrove di Perairan Pesisir Sulawesi Selatan. Jurnal Ilmu Kehutanan. Vol VII No.1 - JanuariMaret 2013

Sudarsono Y, Yoga GP, Suryono T. (2005). Kontaminasi logam berat di sedimen: studi kasus pada Waduk Saguling, Jawa Barat. Manusia dan Lingkungan. 12(1):28-42.

Supriharyono. (2007). Konservasi ekosistem sumberdaya hayati di wilayah pesisir dan laut tropis. Pustaka Pelajar, Yogyakarta

Sunarya, W.L.R. kusmadji, A. Djalil, E. Nardin, W. Whardana dan I. M. Idil. (1991). Tumbuhan Sebagai Bioindikator Prncemaran udara Oleh Timbal Prosi Dari Seminar Hasil Penelitian Perguruan Tinggi. Direktorat Pembinaan Penelitian Dan Pengabdian Pada Masyarakat. Depdikbud Jakarta.

Ulqodry, T. Z. (2001). Kandungan Logam Berat dalam Jaringan Mangrove Sonneratia Alba dan Avicennia Marina di Pulau Ajkwa dan Pulau Kamora, Kabupaten Timika, Рариа. Program Studi Ilmu Kelautan Universitas Diponegoro.Semarang.

Zhu, Y.L., E.A.H. Pilon-Smits, L. Jouanin and N. Terry. (1999). Overexpression of glutathione synthetase in Indian mustard enhances cadmium accumulation and tolerance. Plant Physiol. 119:73-79. 